\title{
KAJIAN KONSEP KECERDASAN SPIRITUAL BERDASAR KISAH LUQMAN DALAM AL-QUR'AN
}

Noer Rohmah' ${ }^{1}$, Roihanah ${ }^{2}$

${ }^{1}$ STIT Ibnu Sina Malang, Indonesia

${ }^{2}$ IAI Al Qolam Malang, Indonesia

Email: noerzainal77@gmail.com ${ }^{1}$,roihanah65@gmail.com ${ }^{2}$

\begin{tabular}{l|l|l} 
Received: Desember 2021 & Accepted: Desember 2021 & Published: Januari 2022 \\
\hline
\end{tabular}

\begin{abstract}
Spiritual intelligence is an important study in the world of education because of its impact and role in shaping meaningful human beings in life. Humans who have closeness to God as well as concern for others. For this reason, Islamic education requires a concept of spiritual intelligence that can be applied to form a generation of Muslims with this type of intelligence. This study seeks to produce the concept of spiritual intelligence based on the verses of the Qur'an, about the Luqman family story contained in Surah Luqman verses 12-19. Through library research, data was collected using documentation techniques, then analyzed using the maudhu'i or thematic method, by discussing the verses of the Qur'an based on the theme. The results of the study explain that there are several aspects of spiritual intelligence in the surah and the verse, namely: spiritual aspects which include the command to be grateful, not to commit shirk, being able to do good and prevent evil, and being able to be patient. Furthermore, the biological aspect is the command to establish prayer and the social aspect which includes: the necessity to always obey both parents and get along with fellow humans with good association. Then some aspects of this spiritual intelligence can be actualized in the implementation of the pillars of Islam, the pillars of faith and ihsan.
\end{abstract}

Kata Kunci: spiritual intelligence, luqman story, Islamic education

\begin{abstract}
Abstrak: Kecerdasan spiritual menjadi kajian yang penting dalam dunia pendidikan karena dampak dan perannya dalam membentuk manusia-manusia bermakna dalam kehidupan. Manusia-manusia yang memiliki kedekatan dengan Tuhan sekaligus kepedulian terhadap sesama. Untuk it, dunia pendidikan Islam memerlukan sebuah konsep kecerdasan spriritual yang dapat diaplikasikan untuk membentuk generasi muslim dengan jenis kecerdasan tersebut. Kajian ini berupaya untuk menghasilkan konsep kecerdasan spiritual yang didasarkan pada ayat-ayat al-Qur'an, yaitu pada satu kisah keluarga Luqman yang termaktub dalam surah Luqman ayat 1219. Melalui studi kepustakaan, data dikumpulkan dengan teknik dokumentasi, kemudian dianalis menggunakan metode maudhu'i atau tematik yakni dengan membahas ayat Al Qur'an berdasarkan tema. Adapun hasil penelitian menjelaskan bahwa ada beberapa aspek mengenai kecerdasan spiritual yang surah dan ayat tersebut, yaitu: aspek rohani yang meliputi perintah untuk bersyukur, tidak berbuat syirik, mampu melakukan yang baik dan mencegah kemungkaran, dan mampu untuk bersabar. selanjutnya aspek biologis yaitu perintah untuk mendirikan salat dan aspek sosial yang meliputi: keharusan untuk selalu taat kepada kedua orang tua dan bergaul kepada sesama manusia dengan pergaulan yang baik. Kemudian beberapa aspek kecerdasan spiritual ini dapat diaktualisasikan dalam pelaksanaan rukun Islam, rukun iman dan ihsan.
\end{abstract}

Kata Kunci: kecerdasan spiritual, kisah luqman, pendidikan Islam 


\section{A. Pendahuluan}

Manusia sejak dilahirkan telah memiliki kemampuan untuk berkembang sesuai dengan fitrahnya, yang selanjutnya fitrah tersebut akan berkembang tergantung dari pengaruh lingkungannya yakni lingkungan keluarga, sekolah dan masyarakat. Salah satu potensi manusia sejak lahir adalah kecerdasan, yang meliputi kecerdasan intelektual, emosional dan spiritual ( IQ, EQ, dan SQ) ketiganya ini ikut berperan dalam mengembangkan kepribadian manusia itu sendiri. Kecerdasan spiritual sangat fundamental sebagai landasan awal pembentukan generasi. Kecerdasan spiritual seseorang akan memberi dampak pada intelektualnya (IQ) dan emosional-nya (EQ).1 Menurut beberapa penelitian IQ hanya berperan 5\%-20\% dalam mengantarkan seseorang meraih kesuksesan, bahkan menurut Institut Teknologi Carnegie Amerika, dari sepuluh ribu orang yang sukses, 15\% karena kemampuan intelektual, 85\% karena faktor kepribadian. ${ }^{2}$

Kecerdasan spiritual merupakan bagian inti dari kecerdasan manusia. Kecerdasan ini mampu membuat manusia menyadari siapa dirinya sesungguhnya, dan bagaimana seharusnya ia hidup agar lebih bermakna. Pemahaman kepada siapa dirinya ini akan mengatarkan manusia kepada tujuan hidup yang sesungguhnya sehingga tiada pilihan lain dalam hidup ini selain munculnya motivasi yang kuat agar hidupya bisa memberi makna. Kehidupan spiritual ini meliputi hasrat untuk hidup bermakna (The Will To Meaning), yang memotivasi kehidupan manusia untuk senantiasa mencari makna hidup (The Meaning of Life), dan mendambakan hidup bermakna (The Meaningful Life). ${ }^{3}$ Oleh karena itu setiap sikap dan perilaku dalam hidupnya selalu berdimensi ketuhanan dan kemanusiaan secara totalitas.

Berbagai uraian tentang dampak dan peran kecerdasan spiritual di atas menunjukkan pentingnya kecerdasan ini bagi manusia. Hal ini yang melatarbelakangi peneliti untuk mengkaji tema kecerdasan spiritual ditinjau dari sisi agama, yaitu agama Islam. Terdapat kenyataan bahwa sejatinya Islam mengajarkan konsep kecerdasan spiritual melalui kisah-kisah, baik secara tersurat maupun tersirat. Salah satu kisah tersebut adalah kisah Luqman dalam mendidik anak-anaknya. Kisah ini terhimpun dalam Qur'an surah Al Luqman Ayat 12-19. Melalui kisah tersebut akan dapat digali konsep kecerdasan spiritual yang meliputi aspek-aspek kecerdasan spiritual yang harus dimiliki seorang manusia, dan bentuk aktualisasinya bagi umat muslim.

\footnotetext{
${ }^{1}$ Danah Zohar dan Ian Marshall, SQ-Kecerdasan spiritual (Bandung: Mizan Pustaka, 2007), hlm. 4.

2 Ary Ginanjar Agustian dan Ridwan Marzuki, ESQ For Teens (Jakarta: PT Arga Publishing, 2007), hlm. 19.

${ }^{3}$ Abdul Mujib dan Yusuf Mudzakir, Nuansa-Nuansa Psikologi islami (Jakarta: PT Raja Grafindo Persada, 2002), hlm. 325.
} 


\section{B. Metode Penelitian}

Kajian ini merupakan penelitian pustaka (library research) yaitu menjadikan bahan pustaka sebagai sumber data utama. Data yang diteliti berupa naskah-naskah atau buku-buku, atau majalahmajalah yang bersumber dari khazanah kepustakaan. ${ }^{4}$ Metode pengumpulan data dalam penelitian ini adalah metode dokumentasi, 5 yaitu berupaya menggali data yang terkait dengan kecerdasan spiritual yang terdapat dalam surat Al Luqman Ayat 12-19. Sumber data ini meliputi data primer yakni langsung terkait dengan obyek penelitian yaitu Al Qur'an dan terjemahannya, tafsir Ibnu Katsir, tafsir Jalalain, tafsir al Maroghi, dan kitab Riyadlus Sholihiin. Sedangkan sumber data sekunder meliputi; buku-buku atau karya ilmiah yang isinya dapat melengkapi data yang diperlukan penulis dalam penelitian ini.

Analisis data dengan menggunakan metode deskriptif analitik, yaitu menggambarkan bagaimana konsep kecerdasan spiritual dalam surat Luqman Ayat 12-19 secara sistematis, pendapat para ahli yang relevan juga digunakan. Tahap berikutnya adalah interpretasi, yaitu memahami seluruh konsep kecerdasan spiritual dalam surat Luqman Ayat 12-19 untuk mendapatkan data sesuai dengan fokus penelitian. Dalam penelitian kali ini penulis menggunakan cara berfikir deduktif. 6 Selanjutnya untuk mencari jawaban dari permasalahan yang dirumuskan maka penulis menggunakan Metode Maudhu'i atau Tematik, ${ }^{7}$ yakni dengan menjelaskan ayat Alqur'an sesuai tema atau judul yang sudah ditetapkan.

\section{Hasil dan Pembahasan}

\section{Aspek Kecerdasan Spiritual Yang Terkandung Pada Pesan Luqman Dalam Surat Luqman} Ayat 12-19

Kecerdasan spiritual merupakan kemampuan untuk memberi makna ibadah terhadap setiap perilaku dan kegiatan, melalui langkah-langkah dan pemikiran yang bersifat fitrah dalam upaya menggapai kualitas hanif dan ikhlas. Kecerdasan spiritual berfungsi memberikan makna hidup, agar seseorang dapat memandang hidup dengan pandangan yang lebih luas. Berdasakan hasil kajian tentang konsep kecerdasan spiritual berdasar kisah Luqman pada Qs. Luqman ayat 12-19, berikut merupakan aspek-aspek kecerdasan spiritual yang dapat diambil dari kisah tersebut:

\footnotetext{
${ }^{4}$ Moh Nazir, Metode Penelitian (Jakarta: Ghalia Indonesia, 1998), hlm. 54.

5 Suharsimi Arikunto, Prosedur Penelitian Suatu Pendekatan Praktik (Jakarta: Rineka Cipta, 2006), hlm.

${ }^{6}$ Sutrisno Hadi, Metodologi research (Yogyakarta: Andi Offset, 1993), hlm. 36.

${ }^{7}$ Nasruddin Baidan, Metode Penafsiran Al-Quran (Yogyakarta: Pustaka Pelajar, 2002), hlm. 72.
} 131. 
a. Surat Luqman Ayat 12

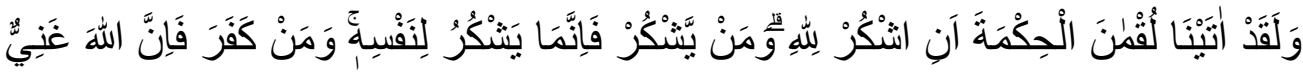

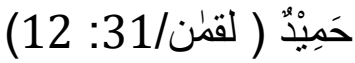

"Dan sungguh, telah Kami berikan hikmah kepada Lukman, yaitu, "Bersyukurlah kepada Allah! Dan barangsiapa bersyukur (kepada Allah), maka sesungguhnya dia bersyukur untuk dirinya sendiri; dan barangsiapa tidak bersyukur (kufur), maka sesungguhnya Allah Mahakaya, Maha Terpuji." (Luqman/31:12)

Ayat 12 dari Qs Luqman bahwa aspek pertama tentang kecerdasan spiritual yang terkandung dalam surat Luqman ayat 12 adalah rasa syukur atas semua takdir Allah. Seseorang yang selalu bersyukur akan nikmat Allah, akan senantiasa merasa berkecukupan terhadap pemberian Allah, dan karena ia memiliki kecerdasan spiritual maka ia akan menerima nikmat, dengan cara menampakkan pada pemberian bahwa ia sangat butuh terhadap pemberiannya dan tidak pernah untuk meminta lebih.

Orang yang ahli syukur berhak mendapatkan tambahan nikmat dan ridhonya. ${ }^{8}$ Syukur yang kita panjatkan dan kita lakukan hakikatnya, bukan untuk Allah, tetapi sebagai bentuk pengertian kita sendiri terhadap kebesaran dan kekuasaan Allah. ${ }^{9}$ Rasa syukur adalah merupakan bentuk aspek kecerdasan spiritual karena dengan bersyukur manusia akan merasa cukup atas apa yang telah diberikan Allah terhadap manusia, seseorang yang mempunyai kecerdasan spiritual tinggi maka akan selalu bersyukur atas apa yang terjadi baik itu dengan kekurangan maupun kelebihan yang ada pada dirinya.

Seseorang yang selalu bersyukur kepada Allah atas segala nikmat yang diberikan maka akan bisa hidup dengan damai.10 Ini dikatakan sebagai aspek kecerdasan spiritual karena dengan aspek syukur ini akan mampu menghadapi masalah eksistensial, termasuk di dalamnya kekhawatiran atas kekurangan yang dimilikinya dan membuat ia mampu untuk mengatasinya. ${ }^{11}$ Dari sini dia mempunyai pandangan bahwa segala sesuatu itu terdapat hikmah di dalamnya.

\footnotetext{
${ }^{8}$ Abdullah bin Muhammad bin Abdurrahman bin Ishaq, Lubabu Tafsir Min Ibni Katsir, trans. oleh M. Abdul Ghoffar dan Abu Hasan Al-Atsari (Jakarta: Pustaka Imam Syafii, 2007), hlm. 669.

${ }_{9}$ Ibrahim Abdul Muqtadir, Wisdom of Luqman El-Hakim; 12 Cara Membentengi Kerusakan Akhlak (Solo: Aqwam Media Profetika, 2008), hlm. 47.

${ }^{10}$ M. Utsman Najati, Belajar EQ dan SQ Dari Sunah Nabi (Bandung: Hikmah, 2006), hlm. 4.

11 Zohar dan Marshall, SQ-Kecerdasan spiritual, hlm. 12.
} 
b. Surat Luqman Ayat 13

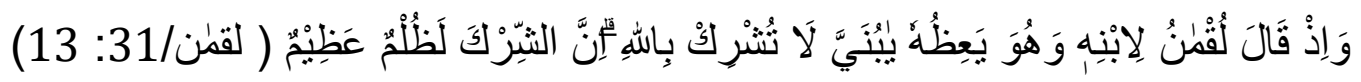

"Dan (ingatlah) ketika Lukman berkata kepada anaknya, ketika dia memberi pelajaran kepadanya, "Wahai anakku! Janganlah engkau mempersekutukan Allah, sesungguhnya mempersekutukan (Allah) adalah benar-benar kezaliman yang besar." (Luqman/31:13)

Ayat 13 dari Qs Luqman memerintahkan untuk tidak berbuat syirik kepada Allah. ${ }^{12}$ Ini merupakan bagian dari kecerdasan spiritual, karena dengan tidak melakukan perbuatan syirik maka hati menjadi bersih, dan jiwa akan semakin tenang. Jiwa yang tenang ini akan memotivasi manusia untuk selalu berbuat positif dan mengakui keesaan Allah.

Syirik merupakan perbuatan yang zalim dan dosa besar, oleh karenanya larangan syirik ini termasuk dalam aspek kecerdasan spiritual, karena dengan menghindari syirik maka seseorang tidak dibayangi oleh bayang-bayang semu yang menjadikan jiwanya lemah dan merasa bimbang. Orang yang jiwa atau rohaninya lemah maka akan memiliki kekosongan rohani, dan orang yang memiliki kekosongan rohani maka ia akan melakukan segala sesuatu tidak atas dasar kebaikan. Syirik tidak lain hanyalah kebohongan belaka yakni mengadakan kedustaan terhadap Tuhan. ${ }^{13}$ oleh karenanya larangan syirik ini termasuk dalam aspek kecerdasan spiritual, karena dengan menghindari syirik maka seseorang tidak dibayangi oleh bayang-bayang semu yang menjadikan jiwanya lemah dan merasa bimbang.

c. Surat Luqman Ayat 14 dan 15

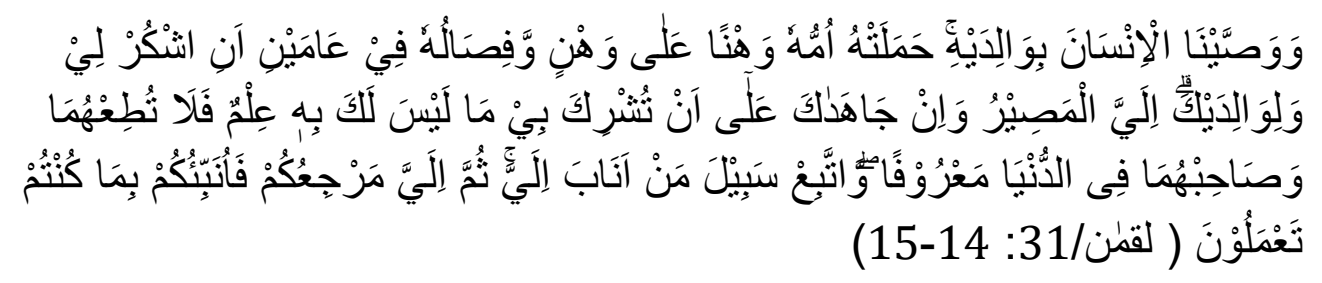

“(14)Dan Kami perintahkan kepada manusia (agar berbuat baik) kepada kedua orang tuanya. Ibunya telah mengandungnya dalam keadaan lemah yang bertambah-tambah, dan menyapihnya dalam usia dua tahun. Bersyukurlah kepada-Ku dan kepada kedua orang tuamu. Hanya kepada Aku kembalimu. (15) Dan jika keduanya memaksamu untuk mempersekutukan Aku dengan sesuatu

12 Hasbi Ash Shiddieqie, Tafsir Al Quranul Majid (Semarang: PT Pustaka Rizki Putra, 2000), 3207.

13 Toshikio Izutsu, Konsep Konsepetika Religious Dalam Quran (Yogyakarta: PT. Tiara wacana Yogya, 1993), hlm. 157. 
yang engkau tidak mempunyai ilmu tentang itu, maka janganlah engkau menaati keduanya, dan pergaulilah keduanya di dunia dengan baik, dan ikutilah jalan orang yang kembali kepada-Ku. Kemudian hanya kepada-Ku tempat kembalimu, maka akan Aku beritahukan kepadamu apa yang telah kamu kerjakan." (Luqman/31:14-15).

Ayat 14 dan 15 dari Qs Luqman menerangkan perintah berbakti kepada kedua orang tua, dan pentingnya berbakti kepada kedua orang tua, kecuali jika orang tua menyuruh berbuat syirik, maka tidak boleh ditaati. ${ }^{14}$ Ayat diatas termasuk kedalam aspek sosial atau interaksi sosial, dan aspek rohani. Di mana berbakti dan menghormati kedua orang tua adalah suatu kewajiban bagi seorang anak terhadap keduanya.

Ayat tersebut memberikan pelajaran bahwa taatnya seorang anak kepada kedua orang tua merupakan bagian dari ketaatannya kepada Allah. Sedangkan masuk kedalam aspek rohani karena ini bersangkutan dengan Hablum Mina Allah, yakni hubungan manusia dengan Tuhannya, karena orang yang memiliki kecerdasan spiritual tinggi maka ia dapat membangun diri secara utuh, dan memiliki keyakinan yang kuat karena ia memiliki visi dan tujuan hidup yang kuat. Surat Luqman ayat 15 ini terdapat aspek kecerdasan spiritual yakni wala dan bara. ${ }^{15}$ Kedua aspek tersebut masuk dalam aspek rohani dan aspek sosial, dimana aspek rohani berkaitan dengan keimanan dan keyakinan yang ada pada seseorang, dan aspek sosial perlunya menaati kedua orang tua meski orang selagi dalam urusan keduniaan dan bukan masalah keimanan.

d. Surat Luqman Ayat 16

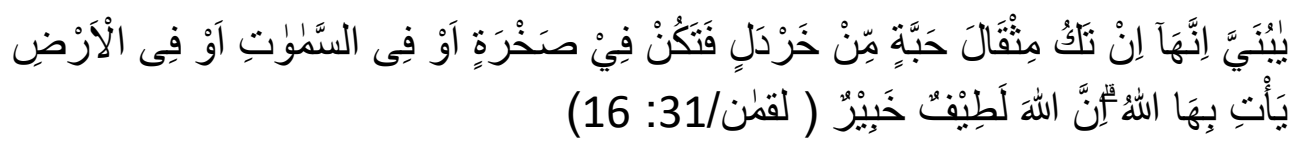

"(Lukman berkata), "Wahai anakku! Sungguh, jika ada (sesuatu perbuatan) seberat biji sawi, dan berada dalam batu atau di langit atau di bumi, niscaya Allah akan memberinya (balasan). Sesungguhnya Allah Mahahalus, Mahateliti." (Luqman/31:16).

Ayat 16 dari Qur'an surah Luqman menjelaskan keluasan dan kedalaman ilmu Allah, Allah mengetahui segala sesuatu yang ada di hati manusia. Ayat diatas menunjukkan balasan amal kebaikan selama di dunia. Barang siapa selama di dunia berbuat baik dan menghargai orang lain, maka tidak luput lah Allah memberikan balasan pahala kepadanya. Orang yang memiliki kecerdasan spiritual yang tinggi senantiasa melakukan hal-hal terpuji

${ }^{14}$ Ash Shiddieqie, Tafsir Al Quranul Majid, hlm. 3207.

${ }^{15}$ Izutsu, Konsep Konsepetika Religious Dalam Quran, hlm. 100. 
yang tidak bertentangan dengan hati nuraninya, dan ia selalu waspada dan berhati-hati terhadap apa yang diperbuatnya. Karena ia tahu bahwa Allah menegakkan timbangan amal yang dilakukan oleh hambanya dengan adil. Ayat ke enam belas ini berkaitan dengan aspek rohani yang dapat meningkatkan kualitas kecerdasan spiritual yang dimiliki oleh seseorang.

e. Surat Luqman Ayat 17

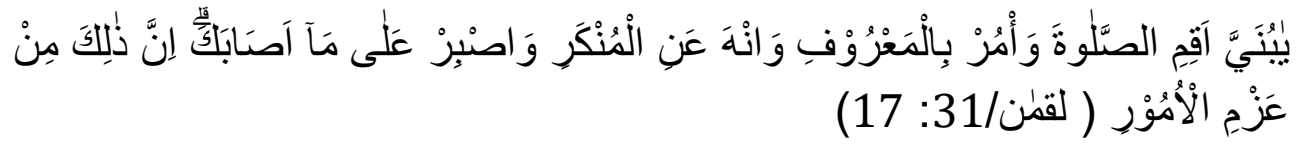

"Wahai anakku! Laksanakanlah salat dan suruhlah (manusia) berbuat yang makruf dan cegahlah (mereka) dari yang mungkar dan bersabarlah terhadap apa yang menimpamu, sesungguhnya yang demikian itu termasuk perkara yang penting." (Luqman/31:17)

Nasehat Luqman pada Qs Luqman ayat 17 adalah perintah untuk menegakkan salat, berbuat baik dan meninggalkan kejelekan, serta perintah bersabar atas apa yang terjadi pada dirinya. Ibadah salat ini masuk kedalam kategori aspek kecerdasan spiritual karena dengan melaksanakan salat jiwa seseorang akan menjadi bersih. ${ }^{16}$ Karena salat seperti cahaya spiritual yang membawa tenaga baru dengan membentuk kepribadian manusia. ${ }^{17}$ Ibadah salat memiliki pengaruh besar untuk memperkuat dan memberikan ketenangan jiwa. ${ }^{18}$ Akan tetapi utsman najati juga menambahkan bahwa salat juga memiliki aspek sosial. 19

Selanjutnya pandangan Luqman mengenai aspek kecerdasan spiritual dalam ayat tersebut adalah perintah untuk amar ma'ruf nahi munkar, hal ini sesuai dengan aspek sosial dan rohani. Aspek sosial karena seseorang dapat berbuat baik dalam lingkungan dimana dia hidup, aspek rohani karena seseorang dapat terhindar dari perbuatan yang tidak diridhoi oleh Allah. Dengan melakukan amal kebaikan dan mencegah kemungkaran ini, maka seseorang dapat meningkatkan kualitas kecerdasan spiritualnya.

Nasehat berikutnya adalah perintah bersabar atas apa yang terjadi pada dirinya. Kemudian bersabar atas apa yang menimpa seseorang, orang yang memiliki tingkat kecerdasan spiritual yang tinggi, maka ia akan mudah sekali untuk bersabar, ia akan selalu berlapang dada atas semua kejadian dalam hidupnya, apakah yang bersifat kenikmatan

${ }^{16}$ Najati, Belajar EQ dan SQ Dari Sunah Nabi, hlm. 4.

${ }^{17}$ Najati, hlm. 28.

${ }_{18}$ Ahmad Thib dan Siti Musdah, Menyelami seluk-beluk ibadah dalam Islam (Jakarta: Prenada Media, 2003), hlm. 181.

${ }^{19}$ Najati, Belajar EQ dan SQ Dari Sunah Nabi, hlm. 5. 
hidup yang menyenangkan ataupun musibah dalam hidup yang menyusahkan. Semua itu akan dilewatinya dengan mudah dan tidak merasa beban. Karena ia memandang hidup ini tidak hanya dari satu sisi saja, melainkan ia mampu memaknai hidup ini dari berbagai segi.

f. Surat Luqman Ayat 18 dan 19

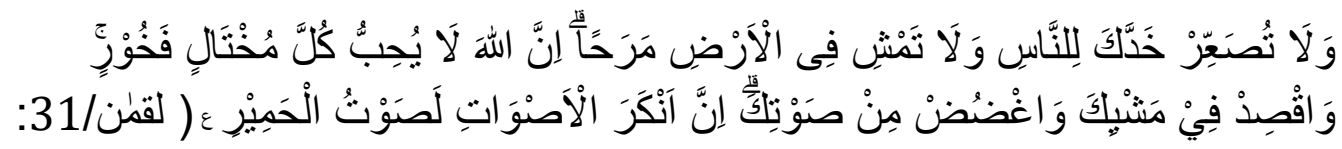

$(19-18$

“(18) Dan janganlah kamu memalingkan wajah dari manusia (karena sombong) dan janganlah berjalan di bumi dengan angkuh. Sungguh, Allah tidak menyukai orang-orang yang sombong dan membanggakan diri. (19) Dan sederhanakanlah dalam berjalan dan lunakkanlah suaramu. Sesungguhnya seburuk-buruk suara ialah suara keledai." (Luqman/31:18-19).

Ayat 18 dan 19 dari Qs Luqman menjelaskan nasihat Luqman kepada anaknya tentang bagaimana cara berjalan, yaitu hendaknya jangan terlalu cepat dan jangan terlalu perlahan, dan menjelaskan bagaimana etika berbicara yaitu, hendaknya jangan bersuara terlalu keras hingga menyerupai keledai. Kedua ayat tersebut masuk dalam kategori aspek sosial, karena di jelaskan bagaimana hubungan manusia dengan manusia, yakni tidak boleh untuk memalingkan muka ketika berbicara, karena hal seperti itu ( berpaling muka) bagian dari sikap sombong dan angkuh, kurang menghargai orang lain. Hal ini tidak seharusnya dimiliki oleh orang yang memiliki kecerdasan spiritual yang tinggi.

Larangan untuk bersikap sombong juga dipesankan dalam surat Luqman tersebut. Utsman Najati berpendapat bahwa larangan bersikap sombong ini masuk kedalam aspek jiwa, karena ia dapat menahan gejolak jiwanya ketika berinteraksi dan bersosialisasi dengan sesama. ${ }^{20}$ Sombong adalah salah satu bentuk perbuatan syaitan yang sangat dibenci oleh Allah, dan orang yang memiliki kecerdasan spiritual yang tinggi maka akan terjaga dari sifat sombong ini.

Beberapa aspek kecerdasan spiritual yang terkandung dalam surat Luqman ayat 12-19 sebagaimana uraian di atas dapat diarahkan pada kesimpulan bahwa aspek kecerdasan spiritual, yang harus dimiliki manusia dapat dibagi menjadi tiga aspek: aspek rohani, aspek biologis dan aspek sosial. Berikut rincian dari ketiga aspek tersebut:

${ }^{20}$ Najati, hlm. 6. 
a. Aspek Rohaniah yang meliputi:

1) Keharusan bersyukur kepada Allah atas segala nikmat yang telah diberikan dalam hidup, dan mampu menggunkaan sebaik-baiknya sehingga dalam menjalani hidup ini penuh dengan kedamaian, ini terdapat dalam surat Luqman ayat 12.

2) Tidak berbuat syirik kepada Allah yakni tidak meminta sesuatu kepada selain Allah atau tidak menyamakan Allah dengan sesuatu selain Allah, ini ada dalam surat Luqman ayat 13 .

3) Memiliki keteguhan hati atau berpegang pada keyakinan hati nurani, karena hati nurani tidak pernah ingkar pada Allah, ini sesuai dengan ayat 15 dalam surat luqman.

4) Menghindari perbuatan yang bertentangan dengan hati nurani, dan harus yakin bahwa segala tingah laku kita tidak pernah luput dari pengawasan Allah, ini sesuai dengan surat Luqman ayat 17.

5) selalu melakukan amal baik dan menghindari perbuatan kemungkaran ( Amar Ma'ruf Nahi Munkar), karena inilah salah satu jalan untuk mencapai Ridlo Allah, ini ada dalam surat Luqman ayat 17.

6) Mampu menjalani hidup dengan penuh kesabaran, karena orang yang sabar akan mampu mengendalikan diri dan selalu bisa menerima dengan penuh lapang dada apapun ketentuan Allah dalam hidupnya setiap hari, sehingga hidupnya lebih tenang dan damai, ini sesuai dengan surat Luqman ayat 17 pula.

b. Aspek biologis yaitu mendirikan salat. Salat merupakan ibadah badaniyah pertama kali yang diwajibkan oleh Allah sebelum ibadah badaniyah yang lain. Ibadah badaniyah adalah ibadah yang bersifat fisik, ibadah yang bersifat gerak-gerik badan, sehingga badan dan tubuh kita akan selalu merasa sehat dan kuat, ahli ilmu kedokteran juga mengungkap hal ini. Hal ini sesuai dengan surat Luqman ayat 17.

c. Aspek sosial yang terdiri dari:

1) Berbakti atau taat kepada kedua orang tua selagi mereka menyuruh melakukan kebaikan, karena ridhonya Allah juga tergantung pada ridhonya kedua orang tua. Dan sebaliknya jika mereka memerintahkan kepada hal-hal yang menyimpang dari agama, maka tidak boleh ditaati, ini ada dalam surat Luqman ayat 14 .

2) Melakukan Amar Ma'ruf Nahi Munkar orang yang memiliki kecerdasan spiritual akan mengetahui bagaimana cara bergaul dengan baik, dan dia dapat berbuat baik pada lingkungan dimana dia hidup. Ini seiring dengan ayat 17. 
3) Mampu bergaul dengan semua manusia dengan pergaulan yang baik, yakni dengan tidak berpaling muka ketika berbicara, tidak angkuh dan tidak sombong, bertutur kata yang baik dan rendah hati, ini sesuai dengan ayat 18-19 dalam surat Luqman.

\section{Aktualisasi Kecerdasan Spiritual yang Terkandung pada Pesan Luqman}

Dalam kehidupan nyata sehari- hari sering kali ditemukan sikap-sikap yang sesuai dengan keberadaan suatu masyarakat, sikap-sikap yang menuntut seseorang untuk memiliki kecerdasan spiritual. Dalam surat Luqman ayat 12-19 terdapat bagaimana seseorang yang memiliki kecerdasan spiritual dalam mengaktualisasikan dirinya dalam kehidupan sehari-hari. Rincian dalam surat tersebut memberikan penjelasan bahwa aktualisasi kecerdasan spiritual dalam hidup keseharian ini sangat diperlukan untuk berinteraksi dengan dengan Allah maupun interaksi dengan sesama manusia. Dalam bersosialisasi diperlukan aktualisasi kecerdasan spiritual dalam kehidupan seharihari diantaranya yaitu:

a. Melalui Rukun Islam

1) Syahadat

Aktualisasi kecerdasan spiritual melalui syahadat ini sesuai dengan surat Luqman Ayat 13. Dan dari ayat tersebut terdapat nasehat Luqman terhadap anaknya yaitu larangan melakukan perbuatan syirik atau menyekutukan Allah. Orang yang mengaku benar-benar telah beriman kepada Allah maka dia tidak akan berani untuk menyekutukan Allah dengan sesuatu selain Allah. Hal ini semata- mata dilakukan karena sebagai bukti penghambaannya kepada Allah karena telah mengucapkan dua kalimat syahadat, yaitu mengakui keesaan Allah dan mengakui bahwa tiada Tuhan selain Allah. Orang yang benar-benar menghamba hanya kepada Allah, maka dia tidak akan berani menghamba pada sesuatu selain Allah ( apakah itu pangkat, jabatan, harta, kekayaan atau yang lainnya), karena hatinya benar-benar sudah tertuju hanya kepada Allah. Dan orang yang memiliki kecerdasan spiritual maka ia akan selalu berbuat sesuai dengan kata hatinya, dan membuat dirinya selalu taat atas apa yang diperintahkan.

2) Salat

Salat adalah ibadah badaniyah yang pertama kali diwajibkan oleh Allah, mendahului semua ibadah badaniyah yang lain. Salat juga ibadah yang paling keras perintahnya, melebihi kerasnya perintah untuk ibadah-ibadah lainnya. ${ }^{21}$ Dalam kondisi bagaimanapun selama

21 Muhammad Djarot Sensa, QQ Quranic Quotient: Kecerdasan Kecerdasan Bentukan Al-Quran (Yogyakarta: Penerbit Hikmah, 2005), hlm. 164. 
masih ada kesadaran ingat kepada Allah, seseorang diwajibkan melakukan salat lima waktu. Aktualisasi kecerdasan spiritual melalui salat ini sesuai dengan surat Luqman ayat 17. Ayat inilah yang paling banyak mengandung wasiat, diantaranya perintah untuk selalu mengerjakan salat. Nilai salat, selain terletak pada khuduk (patuh dan disiplin mengikuti contoh gerakan-gerakan jasmani Rasulullah dalam salat) dan khusyu', juga terletak pada sejauh mana salat itu dapat membuahkan amal kebaikan dan menjauhkan dari perbuatan tercela. Hanya dengan demikian, salat insyaallah mempunyai nilai ibadah yang diterima oleh Allah SWT. tidak hanya sekedar kerangka ibadah formalitas belaka dengan gerak - gerik badan tertentu.

Salat merupakan amal ibadah manusia yang pertama-tama diperhitungkan (di hisab) oleh Allah di akhirat nanti, yang semua amal lain akan bergantung pada hasil pemeriksaan terhadap amal salat ini. Salat juga merupakan syarat pertama dari kebahagiaan orang-orang yang beriman yang akan menjadi pewaris syurga. ${ }^{22} \mathrm{Hal}$ ini sebagaimana diterangkan dalam surat $\mathrm{Al}$ Mukminun ayat 1-11 yang artinya:

"Sesungguhnya beruntunglah orang-orang yang beriman yaitu mereka yang khusyu' dalam salatnya, mereka yang menunaikan zakat, dan mereka yang menjaga kemaluannya kecuali terhadap istri-istrinya atau budak yang mereka kuasai, maka sesungguhnya mereka tiada tercela. Barang siapa mencari yang dibalik itu, maka merekalah orang-orang yang melampaui batas. Dan orang-orang yang memelihara amanat-amanat dan janjinya serta memelihara salatnya, mereka itulah orang-orang yang akan mewarisi surga Firdaus, mereka kekal di dalamnya" (QS. Al Mukminun ayat: 1-11).

b. Melalui Rukun Iman

1) Iman Kepada Allah

Allah adalah Tuhan yang mengetahui apapun perbuatan yang dilakukan oleh seorang hamba, tidak ada sedikitpun perbuatan manusia yang terlewatkan dari pantauan Allah. Karenanya apabila kita akan melakukan suatu perbuatan hendaknya selalu karena Allah bukan karena yang lain. Kita harus yakin bahwa hanya dengan bersandar dan bergantung kepada Allah, kita akan selalu siap menghadapi apapun permasalahan dalam hidup ini. Dengan selalu berprinsip kepada-Nya dan berpedoman dengan sifat-sifat Allah maka dalam diri kita akan terpancar suatu kharisma yang kuat.23 Hal yang demikian ini juga telah diterangkan dalam surat Luqman ayat 13 sebagaimana yang telah disebutkan di atas, yakni

22 Imam Al Ghazali, Bimbingan Untuk Mencapai Tingkat Mukmin (terjemahan) (Bandung: CV. Diponegoro, 1995), hlm. 78.

${ }^{23}$ Agustian dan Marzuki, ESQ For Teens, hlm. 241. 
adanya larangan keras untuk menyekutukan Allah, karena dengan menyekutukan Allah maka hati akan menjadi lemah

2) Iman Kepada Ketentuan Allah

Orang yang beriman kepada ketentuan Allah maka ia akan dapat memahami pentingnya sebuah proses hidup yang harus dilalui. ${ }^{24}$ Dengan mengaktualisasikan kecerdasan spiritual melalui sikap beriman kepada ketentuan Allah maka ia akan selalu memiliki sifat sabar dan syukur, ini seiring dengan penjelasan dalam Surat Luqman ayat 12 dan 17. Ayat kedua belas menjelaskan perintah untuk pandai mensyukuri atas segala nikmat yang telah dikaruniakan oleh Allah kepada hambanya. Orang yang pandai mensyukuri nikmat, akan selalu memiliki sikap tawakal. Sikap yang tepat untuk mengatasi semua problem hidup adalah dengan sikap tawakal, seseorang pasrah kepada Allah atas keputusan apapun yang Allah berikan kepada hambanya setelah berusaha secara maksimal. Jika dikaruniai sebuah kebaikan membuatnya bersyukur, sebaliknya jika diberi musibah membuatnya bersabar, syukur dan sabar inilah pilar sikap orang-orang yang lurus dan tawakal kepada Allah. ${ }^{25}$ Sikap tawakal ini adalah cerminan hubungan baik antara manusia dengan Tuhannya.

Selanjutnya sikap sabar karena dengan bersabar seseorang akan memandang arti hidup dari berbagai segi sebagaimana yang telah dijelaskan sebelumnya dalam surat Luqman ayat 17 tentang perintah untuk selalu bersabar dalam menjalani roda kehidupan ini. Karena Menurut Al-Quran, orang mukmin yang benar-benar bertakwa adalah yang mampu bersabar ketika menghadapi kesulitan dan penderitaan, dan mereka mampu bersyukur ketika mendapatkan berbagai macam kenikmatan, sehingga mampu mempergunakannya untuk sesuatu yang diridhoi-Nya.

c. Melalui Ihsan

1) Tanggung Jawab

Tanggung jawab merupakan suatu perbuatan yang berat, karena di dalam tanggung jawab terdapat suatu keharusan, seperti menghormati dan menjaga kedua orang tua ini merupakan keharusan dan tanggung jawab pada setiap individu untuk melaksanakannya. Karena begitu besar jasa dan pengorbanan kedua orang tua kepada kita. Aktualisasi kecerdasan spiritual melalui Al Ikhsan ini sesuai dengan surat Luqman ayat 14 dan 15 . Ayat tersebut mengisyaratkan adanya kewajiban untuk berbuat baik dan mematuhi kepada kedua

\footnotetext{
${ }^{24}$ Agustian dan Marzuki, hlm. 239.

${ }^{25}$ Aa Qowiy, 10 Sikap Positif Menghadapi Kesulitan Hidup, ed. oleh Cucu Juanda (Bandung: PT Remaja Rosdakarya, 2005), hlm. 211.
} 
orang tua serta bersyukur. Patuh kepada kedua orang tua di sini tentunya dalam hal-hal yang baik, sehingga jika orang tua menyuruh untuk berbuat ingkar kepada Allah, maka secara mutlak tidak boleh untuk ditaati. Berbakti kepada kedua orang tua adalah perbuatan mulia dan menempati kedudukan tinggi di sisi Allah, kedudukan kedua orang tua dalam Al-Quran sangat terpuji dan tinggi, akan tetapi jika orang tua mengajak dalam kemusyrikan maka janganlah turuti keduanya. Tapi jangan berhenti untuk berbuat baik kepada mereka. Sudah selayaknya manusia menghormati kedua orang tuanya untuk meningkatkan kerohanian. ${ }^{26}$

Penghormatan kepada kedua orang tua adalah manusiawi, bahkan hal ini tidak hanya dilakukan kepada orang tua Islam, orang tua kafirpun harus ditaati selagi tidak mengajak kita untuk menyekutukan Allah. Hal ini membuktikan, bahwa berbuat baik (berbakti) kepada orang tua merupakan perkara yang pertama dan terpenting di dalam urusan hablum minannas setelah mentauhidkan Allah. Dari penjelasan diatas dapat disimpulkan bahwa seorang anak memiliki tanggung jawab untuk menjaga dan menghormati orang tuanya, dan seorang anak juga memiliki tanggung jawab terhadap keyakinan dan agama masing-masing.

2) Disiplin

Disiplin adalah perwujudan bentuk pengabdian seorang hamba kepada sifat Allah Al Matin. ${ }^{27}$ Al Matin adalah sifat Allah yang maha menggenggam kekuatan yaitu kekuatan untuk mengetahui segala sesuatu. Dengan berdisiplin maka seseorang akan dapat melaksanakan tugasnya dengan baik. orang yang memiliki sifat disiplin maka hidupnya akan teratur dan tertib. Disiplin diri ini sangat dibutuhkan karena orang yang memiliki disiplin maka ia tidak akan melakukan sesuatu yang tidak bermanfaat karena ia tahu ada Allah yang selalu mengawasi semua gerak geriknya dan mengetahui apapun yang tersembunyi di dalam hatinya ini sesuai dengan surat Luqman ayat 16. Kali ini mengenai wasiat Luqman terhadap anaknya adalah kedalaman ilmu Allah. Yaitu Allah selalu mengetahui apa-apa yang diperbuat oleh hambanya. Atas sifat Allah yang maha mengetahui maka manusia di tuntut untuk memiliki sifat selalu berbuat baik di hadapan Allah maupun diantara manusia sendiri.

3) Peduli

Peduli adalah wujud pengabdian manusia kepada sifat Allah, As Sami dan Al Bashir.28 Yaitu maha mendengar dan maha melihat. Allah adalah Tuhan yang maha melihat dan mendengar maka ia akan selalu melaksanakan yang ma'ruf dan mencegah yang mungkar, ini sesuai dengan surat Luqman ayat 17 sebagaimana yang telah dijelaskan sebelumnya yakni

\footnotetext{
${ }^{26}$ Mohsen Qaraati, Seri Tafsir untuk Anak Muda: Surah Luqman (Jakarta: Al-Huda, t.t.), hlm. 60.

${ }^{27}$ Agustian dan Marzuki, ESQ For Teens, hlm. 111.

${ }^{28}$ Agustian dan Marzuki, hlm. 111.
} 
perintah untuk selalu beramar ma'ruf dan perintah untuk selalu bersabar dalam menjalani hidup. Rasa peduli ini juga tercermin pada perilaku seseorang dalam hidup sehari hari. Misalnya berbuat sopan dan selalu santun dengan sesama, berbudi pekerti yang luhur dalam pergaulan, selalu menampakkan akhlak mulia dalam pergaulan dengan siapapun, ini sesuai dengan surat Luqman ayat 18 dan 19 tentang etika dalam pergaulan sebagaimana yang telah dijelaskan sebelumnya yakni harus selalu bersikap sederhana, rendah hati, larangan untuk berbuat angkuh, sombong dan membanggakan diri.

Manusia sebagai makhluk sosial, dalam kehidupannya tidak terlepas dari interaksi dengan sesama makhluk, khususnya manusia, sebagai sesama makhluk sosial. Hubungan antara sesama manusia (hablu minannas) sebagai bentuk hubungan hak adami, dan hak adami mempengaruhi hubungan dengan Allah SWT. Keharmonisan hubungan sesama manusia menentukan kadar keharmonisan hubungan manusia dengan Allah swt.

Pendidikan sosial adalah tahapan akhir yang dilakukan Luqman terhadap anaknya. Setelah anak dikenalkan konsep akhlak kepada Tuhannya melalui jalan ibadah, dan kepada kedua orang tuanya maka berikutnya diajarkan padanya akhlak dalam konteks kemasyarakatan. Pendidikan sosial ini mencakup etika pergaulan (bertemu), berbicara, berjalan dan lainnya. Ajaran inilah yang sebenarnya dalam konsep Islam dikenal dengan Ikhsan. Jadi ide pokok pendidikan Luqmanul Hakim kepada anaknya meliputi empat konsep tersebut, dimana dalam istilah lain secara filosofis telah memenuhi target untuk membentuk insan kamil yang terdiri dari kesempurnaan aqidah, syariah dan akhlak.

\section{Kesimpulan}

Hasil kajian tentang konsep kecerdasan spiritual yang terkandung dalam Qs Luqman ayat 12-19 sampai pada temuan kesimpulan bahwa terdapat tiga aspek kecerdasan spiritual yang harus dimiliki oleh manusia, yaitu aspek rohani, biologis dan sosial. Seseorang yang memiliki kecerdasan rohani akan memiliki karakter seperti: bersyukur, tidak berbuat syirik, memiliki keteguhan hati atau berpegang pada keyakinan hati nurani, Menghindari perbuatan yang bertentangan dengan hati nurani, melakukan amal baik, serta memiliki kesabaran. Seseorang yang memiliki kecerdasan biologis akan berupaya mendirikan salat. Sedangkan kecerdasan sosial akan terlihat dari bakti seseorang kepada orang tua, amar ma'ruf nahi munkar dan mampu bergaul dengan pergaulan yang baik. Selanjutnya, bentuk aktual seseorang memiliki kecerdasan spiritual dapat tercermin dari perilaku seseorang dalam menerapkan rukun Islam syahadat dan salat, melaksanakan rukun iman: iman kepada Allah dan kepada takdir Allah, serta berbuat ihsan, yaitu menjadi pribadi yang bertanggung jawab, disiplin serta peduli sesama. 
Hasil kajian memiliki implikasi bagi perkembangan ilmu pendidikan khususnya pendidikan Islam bahwa pendidikan harus mampu mewujudkan berkembangnya kecerdasan spiritual peserta didiknya. Pesan-pesan yang disampaikan Luqman kepada anak-anaknya dalam Qs Luqman ayat 1219 memberikan pemahaman tentang bentuk-bentuk aktualisasi konkrit dari upaya mendidik kecerdasan spiritual bagi kematangan emosional dan sosial generasi masa mendatang.

\section{Daftar Rujukan}

Agustian, Ary Ginanjar, dan Ridwan Marzuki. (2007). ESQ For Teens. Jakarta: PT Arga Publishing.

Al Ghazali, Imam. (1995). Bimbingan Untuk Mencapai Tingkat Mukmin (terjemahan). Bandung: CV. Diponegoro.

Arikunto, Suharsimi. (2006). Prosedur Penelitian Suatu Pendekatan Praktik. Jakarta: Rineka Cipta.

Ash Shiddieqie, Hasbi. (2000). Tafsir Al Quranul Majid. Semarang: PT Pustaka Rizki Putra.

Baidan, Nasruddin. (2002). Metode Penafsiran Al-Quran. Yogyakarta: Pustaka Pelajar.

Hadi, Sutrisno. (1993). Metodologi research. Yogyakarta: Andi Offset.

Ishaq, Abdullah bin Muhammad bin Abdurrahman bin. (2007). Lubabu Tafsir Min Ibni Katsir. Diterjemahkan oleh M. Abdul Ghoffar dan Abu Hasan Al-Atsari. Jakarta: Pustaka Imam Syafii.

Izutsu, Toshikio. Konsep Konsepetika Religious Dalam Quran. Yogyakarta: PT. Tiara wacana Yogya, 1993.

Mujib, Abdul, dan Yusuf Mudzakir. (2002). Nuansa-Nuansa Psikologi islami. Jakarta: PT Raja Grafindo Persada.

Muqtadir, Ibrahim Abdul. (2008). Wisdom of Luqman El-Hakim; 12 Cara Membentengi Kerusakan Akhlak. Solo: Aqwam Media Profetik.

Najati, M. Utsman. (2006). Belajar EQ dan SQ Dari Sunah Nabi. Bandung: Hikmah.

Nazir, Moh. (1998). Metode Penelitian. Jakarta: Ghalia Indonesia.

Qaraati, Mohsen. (2005). Seri Tafsir untuk Anak Muda: Surah Luqman. Jakarta: Al-Huda.

Qowiy, Aa. (2005). 10 Sikap Positif Menghadapi Kesulitan Hidup. Disunting oleh Cucu Juanda. Bandung: PT Remaja Rosdakarya.

Sensa, Muhammad Djarot. (2005). QQ Quranic Quotient: Kecerdasan Kecerdasan Bentukan Al-Quran. Yogyakarta: Penerbit Hikmah.

Thib, Ahmad, dan Siti Musdah. (2003). Menyelami seluk-beluk ibadah dalam Islam. Jakarta: Prenada Media. 
Noer Rohmah, Roihanah

Zohar, Danah, dan Ian Marshall. (2007). SQ-Kecerdasan spiritual. Bandung: Mizan Pustaka. 